\title{
Thermal Analysis of the Effects of Multifaceted Conditions on Performance of Shell-and-Tube Heat Exchanger
}

\author{
Taiwo O. Oni, Ayotunde A. Ojo, Daniel C. Uguru-Okorie, and David O. Akindele
}

\begin{abstract}
A shell-and-tube heat exchanger which was subjected to different flow configurations, viz. counter flow, and parallel flow, was investigated. Each of the flow configurations was operated under two different conditions of the shell, that is, an uninsulated shell and a shell insulated with fiber glass. The hot water inlet temperature of the tube was reduced gradually from $60{ }^{\circ} \mathrm{C}$ to $40{ }^{\circ} \mathrm{C}$, and performance evaluation of the heat exchanger was carried out. It was found that for the uninsulated shell, the heat transfer effectiveness for hot water inlet temperature of $60,55,50,45$, and $40{ }^{\circ} \mathrm{C}$ are $0.243,0.244,0.240,0.240$, and 0.247 , respectively, for the parallel flow arrangement. For the counter flow arrangement, the heat transfer effectiveness for the uninsulated shell are $2.40,2.74,5.00,4.17$, and $2.70 \%$, respectively, higher than those for the parallel flow. The heat exchanger's heat transfer effectiveness with fiber-glass-insulated shell for the parallel flow condition with tube hot water inlet temperatures of 60,55 , 50,45 , and $40{ }^{\circ} \mathrm{C}$ are $0.223,0.226,0.220,0.225$, and 0.227 , respectively, whereas the counter flow condition has its heat transfer effectiveness increased by $1.28,1.47,1.82,1.11$, and $1.18 \%$, respectively, over those of the parallel flow.
\end{abstract}

Index Terms - Flow Configuration, Insulated Shell, Temperature, Heat Transfer Effectiveness, Heat Exchanger.

\section{INTRODUCTION}

A system whose purpose is to transfer heat energy from one fluid (liquid and/or gas) to another fluid of different currents at different temperature by means of varieties of utilities, resulting in heating or cooling of the processed current is known as a heat exchanger [1], [2]. It is used in various fields, for example thermal power plants, process industry, petroleum refining, chemical engineering, recovery of excess heat, food industry, air conditioning engineering, and transportation facilities [1], [3], [4]. The various heat exchangers that exist are the compact, shell-and-tube, counter, parallel and cross flow configurations. Among these, shell-and-tube heat exchanger is mostly used. This is because it has many advantages, among which are wide

\footnotetext{
Published on January 13, 2021.

Taiwo O. Oni, Mechanical Engineering Department, Ekiti State University, Ado-Ekiti, Nigeria.

(e-mail: tooni1610@yahoo.com)

Ayotunde A. Ojo, Mechanical Engineering Department, Ekiti State University, Ado-Ekiti, Nigeria.

(e-mail: ayotunde.ojo @eksu.edu.ng)

Daniel C. Uguru-Okorie, Department of Mechanical and Mechatronics Engineering, Federal University Oye-Ekiti, Nigeria.

(e-mail: danchukus ${ }^{\circledR}$ yahoo.com)

David O. Akindele, Mechanical Engineering Department, Ekiti State

University, Ado-Ekiti, Nigeria.

(e-mail: akindeledavid@ rocketmail.com)
}

applicability, easy replacement of parts, reliable structure, easy cleaning methods, and comparatively small ratio of volume and weight to heat transfer area [1], [3].

The shell-and-tube heat exchanger, shown in Fig. 1, comprises a bundle of hollow tubes installed in a shell such that the axes of the tubes and the shell are parallel. Fluids at different temperatures flow inside and outside the tube, and, consequently, results in transfer of heat. The forced fluid, which are in the shell-side, flow across the shell by means of baffles attached to the shell. The baffles cause the heat transfer enhancement, and, also, sustain unvarying spacing between tubes [5], [6].

Before now, some works have been done by many researchers on shell-and-tube heat exchanger. The impacts of inclination angles of baffle on flow characteristics of fluid in a shell-and-tube heat exchanger were numerically investigated by Thundil-Karuppa-Raj and Ganne [7]. Results of the investigation indicated that the heat exchanger having a baffle inclination angle of $20^{\circ}$ performed better when compared with those of $0^{\circ}$ and $10^{\circ}$.

In an attempt make a provision for the need of industries, a new shell-and-tube heat exchanger for cooling oil was proposed by Yang et al. [6]. The analyses of the results of their investigations were carried out for both the shell-side and tube-side. Overall, the heat exchanger's tube-side demonstrated a very good performance. Furthermore, it was revealed that the tube-side performed slightly higher, compared to the shell-side.

Petinrin and Dare [8] did a performance analysis on different shell-and-tube heat exchangers having diverse shapes of its tube, viz. triangular (STHE_T), rotated triangular (STHE_RT), and the combined (STHE_C) shapes. The results obtained indicated that major part of the heat transfer and pressure drop occurred when there was cross flow between the fluid in the shell and that in the tube. Moreover, the results indicated that the STHE_T was the most desirable, as its heat transfer coefficient was the highest of all the cases considered.

Shahmohammadi and Beiki [9] applied water and, later on, a mixture of water and $\gamma-\mathrm{Al}_{2} \mathrm{O}_{3}$ on a shell-and-tube heat exchanger. Performance was the basis of the investigation on the heat exchanger in each case. The investigation showed that the performance of the heat exchanger that has the mixture of water and $\gamma-\mathrm{Al}_{2} \mathrm{O}_{3}$ was better than the one with only water. 


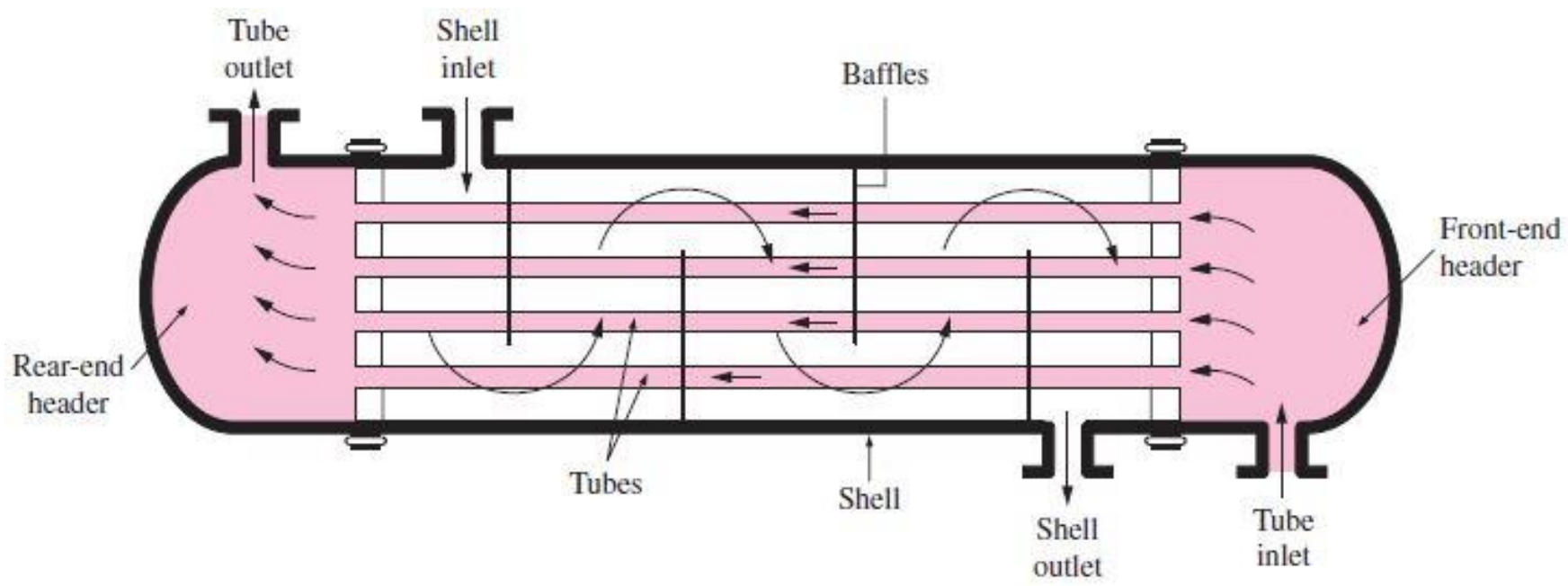

Fig. 1. Shell-and-tube heat exchanger (Cengel [5], p. 670).

Yehia et al. [10] used six swirl vanes positioned at diverse positions along the length of the pipe of a heat exchanger of the shell-and-tube model; to augment its heat transfer. The effect of these swirl vanes on the frictional characteristics of the heat exchanger was also discussed. The approach used was a simulation of the heat exchanger by means of ANSYS Fluent. Pipes with variable diameter $(10 \mathrm{~mm}, 15 \mathrm{~mm}$, and $19 \mathrm{~mm})$ and vanes with different blade angle $\left(15^{\circ}, 30^{\circ}\right.$, and $45^{\circ}$ ) were used for each case. The results showed that the swirl vanes having diameter of $19 \mathrm{~mm}$ and blade angle of $45^{\circ}$ gave the maximum performance, compared with the case of plain tubes.

Dizaji et al. [11] employed a shell and tube marked with ridges, in lieu of a smooth shell and tube, to study experimentally exergetic parameters of a shell-and-tube heat exchanger. Findings obtained confirmed that corrugation caused the exergy to decrease and the number of transfer units (NTU) to increase.

The transfer of heat and generation rate of entropy in shell-and-tube heat exchangers under forced convection were numerically and experimentally studied by Alimoradi and Veysi [12]. The values of dimensionless geometrical parameters that maximized the transfer of heat and minimized the rate of entropy generation were obtained.

Abd and Naji [13] illustrated thermal and mechanical design for a heat exchanger of the shell-and-tube type. A redesign was effected to improve the design by reselecting different parameters which can increase heat transfer through the heat exchanger. Also, a new correlation that predicts Nusselt number for tube side was proposed. Compared with simulation data, the new correlation reduced the error from $15.25 \%$ to $12.64 \%$. The proposed correlation and Kern's correlation were compared against experimental data to show that the proposed correlation was quite accurate.

In order to surmount the susceptibility to vibration of a heat exchanger with a round rod shell and tube (RRBSTHX), a heat exchanger type with a hexagon clamping anti-vibration shell and tube (HCB-STHX) was developed by $\mathrm{Yu}$ et al. [14]. The thermo-hydraulic characteristics of their shell sides were studied numerically, and the fluid velocity effects, as well as the geometry of baffle, on their performance were investigated. It was known, through the results of the investigation, that HCB-STHX, being higher in rigidity than RRB-STHX, would be more appropriate in applications that require tube bundle of large size and heavy weight.

Du et al. [15] used HITEC salt (an eutectic mixture of water-soluble, inorganic salts of potassium nitrate, sodium nitrite, and sodium nitrate) and oil to experimentally study heat transfer characteristics on a shell-and-tube heat exchanger's bundle. The empirical equation of heat transfer of molten salt was applied on the shell-and-tube heat exchanger's shell side. The empirical equation was in agreement with the experimental data with a deviation of $8 \%$. Simulation of the experimental study was carried out, and the experimental data was compared with the simulated data. There was a deviation of $11 \%$ between the experimental data and the simulated data.

The performance of paraffin was evaluated in a novel heat exchanger of a shell-and-tube type, with multi-tube passes and longitudinal fins, by Khan and Khan [16]. The multi-tube passes and longitudinal fins served as the storage unit for latent heat for the heat exchanger. Assessments of the heat exchanger performance showed that when the temperature gradient increased from $52{ }^{\circ} \mathrm{C}$ to $62{ }^{\circ} \mathrm{C}$ between the paraffin and inlet water, the charging power were increased by $75.53 \%$. Not only that, an increase in temperature gradient yielded an improvement in the coefficient of heat transfer and heat transfer effectiveness. Also, it was observed that an increase in the rate of the paraffin's volume flow resulted in reduction in the coefficient of heat transfer and heat transfer effectiveness.

Yang et al. [17] conducted investigations on characteristics of heat transfer of propane in the shell side of vertical and horizontal helically baffled shell-and-tube heat exchangers (HBHXs). The patterns of flow and the coefficients of heat transfer in the shell side of the HBHXs were obtained. The findings showed that the pattern of the variation of propane heat transfer coefficient with the increase of vapor quality was the same in the horizontal and vertical HBHXs. It also showed that the coefficient of heat transfer increased with the increase of heat flux for twophase propane in the vertical HBHX shell side, but the coefficient of heat transfer decreased in the case of horizontal HBHX.

With the intention of intensifying the performance of a shell-and-tube heat exchanger, four segmental baffles of 
different configurations, namely conventional single segmental baffle (CSSB), staggered single segmental baffle (SSSB), flower segmental baffle (FSB), and hybrid segmental baffle (HSB), were used by El-Said and Al-Sood [18] on the heat exchanger, and their performances were compared. The results indicated that SSSB, FSB, and HSB configurations have a significant improvement on the performance of the heat exchanger, and that the effect of HSB configuration on the performance of the heat exchanger was the highest of all test configurations considered.

Khanlari et al. [19] investigated the effect on the performance characteristics of a parallel flow in a concentric tube heat exchanger and a counter flow in the same type of heat exchanger using kaolin/deionized water nanofluid. It was discovered that the nanofluid promoted the performance of the heat exchanger. Specifically, an enhancement of $12 \%$ and $37 \%$ were obtained for the parallel flow and counter flow processes in the concentric tube heat exchanger, respectively.

Yu et al. [20] worked on a compound heat exchanger that has a clamping plate baffle with a longitudinal vortex generator (LVG) incorporated into its shell-and-tube. The heat exchanger's thermal performances with different configurations of LVG were compared. It was inferred from the results that the Nusselt number and friction factor of the compound shell-and-tube heat exchanger increased with the increase in the angle of attack and height of the longitudinal vortex generator.

By integration of the energy obtained from liquid natural gas fueled-ship with an organic Rankine cycle system, and the design of a shell-and-tube heat exchanger in the system, Lim and Choi [21] demonstrated that efficiency of the organic Rankine cycle system can be improved. Five different working fluids (R123, R227ea, R134a, R152a, and R245fa) were applied for analysis of the performance of the cycle. The results of the analysis showed that the R227ea and R123 had the lowest thermal efficiency of 15-21\% and highest thermal efficiency of $17-23 \%$.

It can be observed from the previous works mentioned above that attempt has not been made to investigate the shell-and-tube heat exchanger performance in which the fluid inlet temperature of the tube of the heat exchanger is varied, while the fluid inlet temperature of its shell is not varied. Therefore, this work studies the performance of a shell-and-tube heat exchanger with water as its working fluid, operating under different temperature of hot water inlet temperature in the tube, different configurations of flow (parallel flow and counter flow arrangements), and two different conditions of the shell, namely uninsulated shell and shell insulated with fiber glass.

\section{MethodOLOGY}

The procedures involved in the present work are shelland-tube heat exchanger design, shell-and-tube heat exchanger fabrication, conduct of the experiments, and collection of data. They are presented in details below.

\section{A. Shell-and-Tube Heat Exchanger Design}

The energy balance equation was applied in the design of the heat exchanger, as written in (1):

$q=m_{h} C_{p_{-} h}\left(\theta_{h_{-} i}-\theta_{h_{-} o}\right)=m_{c} C_{p_{-} c}\left(\theta_{c_{-} o}-\theta_{c_{-} i}\right)$

where $q$ denotes the heat transfer; $m_{h}$ and $m_{c}$ represents mass flow rate of the hot fluid and cold fluid, respectively; $C_{p_{-} h}$ and $C_{p_{-} c}$ are the specific heat capacity of the hot fluid and cold fluid, respectively; $\theta_{h_{-} i}$ and $\theta_{h_{-} o}$ are the hot fluid's inlet temperature and outlet temperature, respectively; $\theta_{c_{-} i}$ and $\theta_{c_{-} o}$ are the cold fluid's inlet temperature and outlet temperature, respectively.

The heat exchanger's area is denoted as $A$ in (2) [1]:

$$
N_{t}=\frac{A}{\pi \times D_{t_{-o}} \times L}
$$

That is,

$A=N_{t} \times \pi \times D_{t_{-} o} \times L$

where the number of tube is denoted as $N_{t}, D_{t_{-} o}$ is the outside diameter of the tube, and $L$ stands for the heat exchanger's length.

For the present design, the values of the parameters in (3) above are $N_{t}=8, D_{t_{-} o}=0.024 \mathrm{~m}$, and $L=1.00 \mathrm{~m}$. That is, the area of the heat exchanger is

$$
A=8 \times \pi \times 0.024 \mathrm{~m} \times 1.00 \mathrm{~m}=0.603 \mathrm{~m}^{2}
$$

Arising from the calculations above, the following parameters were selected for the shell-and-tube heat exchanger [3]:

Inside diameter of the tube $\left(D_{t i}\right)=0.021 \mathrm{~m}$

Outside diameter of the shell $\left(D_{S_{-} o}\right)=0.140 \mathrm{~m}$

Inside diameter of the shell $\left(D_{S_{-} i}\right)=0.134 \mathrm{~m}$

\section{B. Production of the Shell-and-Tube Heat Exchanger}

The basic processes involved in the production of the heat exchanger are marking-out, drilling, cutting, and welding. The shell was made by marking, cutting, and rolling a metal plate made of carbon steel to a cylindrical shape, and welding the longitudinal joint. The tubes, which are circular in shape and made of copper pipe, were welded to the shell. It should be noted that the materials used for the tubes and the shell are corrosion-resistant. The standing frame, on which the heat exchanger is mounted, was fabricated by cutting and welding angle iron made of carbon steel. The heat exchanger is presented in Fig. 2.

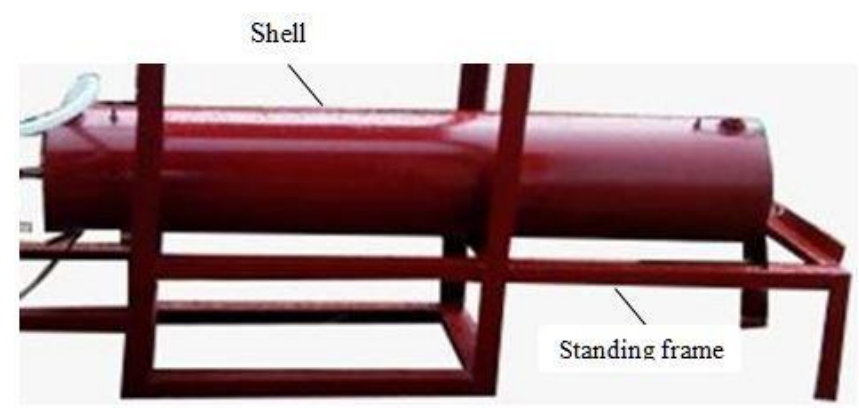

Fig. 2. The shell-and-tube heat exchanger assembly. 


\section{Conduct of the Experiments and Data Acquisition}

The experiments were executed with the shell-and-tube heat exchanger for parallel and counter flow configurations. In the counter flow arrangement, the hot fluid in the tube and the cold fluid in the shell moved in opposite direction, but in parallel flow, they moved in the same direction. For each of the two flow configurations, two different cases of the shell were considered, viz. the case with an uninsulated outer surface shell, and the case with a fiber glass outer surface shell insulation.

The experiments started with parallel flow for the case of uninsulated shell during which hot water at a temperature of $60{ }^{\circ} \mathrm{C}$ and a mass flow rate of $0.3 \mathrm{~kg} / \mathrm{s}$ was passed to the inlet of the tube. Cold water at a temperature of $25{ }^{\circ} \mathrm{C}$ and a mass flow rate of $0.3 \mathrm{~kg} / \mathrm{s}$ was passed to the inlet of the shell. The temperature at the inlet and outlet of the tube and the shell were measured with thermocouples, and the readings were recorded. After that, the cold water to the inlet of the shell was maintained at $25{ }^{\circ} \mathrm{C}$, the inlet temperature of the hot water was reduced to 55, 50, 45 and $40{ }^{\circ} \mathrm{C}$ in succession, and temperatures at the inlet and outlet of the tube and that of the shell were measured with thermocouples, and the readings were recorded.

The experiments were repeated for the other cases, that is counter flow configuration with an uninsulated shell, parallel flow configuration with an insulated shell, and counter flow configuration with an insulated shell.

The real heat transfer (q) in the heat exchanger is mathematically expressed by the energy balance equation [5], presented in (1) above, from which

$q=C_{h}\left(\theta_{h_{-} i}-\theta_{h_{-} o}\right)=C_{c}\left(\theta_{c_{-} o}-\theta_{C_{-} i}\right)$

where $C_{h}=m_{h} C_{p_{-} h}$ and $C_{c}=m_{c} C_{p_{-} c}$ are the heat capacity rates of the hot and the cold fluids, respectively.

The maximum heat transfer $\left(q_{\max }\right)$ is

$q_{\max }=C_{\min }\left(\theta_{h_{-} i}-\theta_{c_{-} i}\right)$

where $C_{\text {min }}$, as provided by Cengel [5], is the lower in value of $m_{h} C_{p_{h}}$ and $m_{c} C_{p_{-} c}$.

The heat transfer effectiveness $(\psi)$ is expressed as the ratio of the real heat transfer to the maximum obtainable heat transfer [1], [3]. That is,

$\psi=\frac{q}{q_{\max }}$

$=\frac{\text { Real rate of heat transfer }}{\text { Maximum obtainable rate of heat transfer }}$

Mathematically,

$$
\begin{aligned}
& \psi=\frac{q}{q_{\max }}=\frac{m_{h} C_{p_{h}}\left(\theta_{h_{i}}-\theta_{h_{o}}\right)}{C_{\min }\left(\theta_{h_{i}}-\theta_{c_{i}}\right)} \\
& =\frac{m_{c} C_{p_{-} c}\left(\theta_{c_{-} o}-\theta_{c_{-} i}\right)}{C_{\min }\left(\theta_{h_{-} i}-\theta_{c_{-} i}\right)}
\end{aligned}
$$

\section{RESUlTS AND ANALYSIS}

The results and their discussions, which are presented in this section, examine the effects of the different configurations of flow and different conditions of the outer surface of the shell of the shell-and-tube heat exchanger on the performance of the heat exchanger. The results and analysis presented in this work are based on the tube hot water inlet temperature $\left(60,55,50,45\right.$, and $\left.40{ }^{\circ} \mathrm{C}\right)$, the shell cold water inlet temperature $\left(25{ }^{\circ} \mathrm{C}\right)$, and the insulation (fiber glass) considered.

Fig. 3 shows that response of the heat exchanger effectiveness to the different flow configurations for the case of an uninsulated shell. As it can be seen in the figure, the heat transfer effectiveness of heat exchanger for the counter flow configuration is greater than that for the parallel flow configuration that was operated under the same conditions. The increase in the heat transfer effectiveness for the counter flow over the parallel flow can be attributed to an improved turbulence of convective air in the counter flow. In the counter flow setup, the directions of the fluid in the tube and the shell were in opposite direction. This caused an increase in the turbulence of air convection in the tube's outer surface and the shell's outer surface, and, consequently, enhanced the heat transfer effectiveness of the heat exchanger for the counter flow configuration. For example, when the tube hot water inlet temperature was 60 ${ }^{\circ} \mathrm{C}$, the heat transfer effectiveness for the parallel flow and counter flow are 0.2431 and 0.2489 , respectively, translating to an increase of $2.40 \%$ for the counter flow over the parallel flow. For the tube hot water inlet temperature at 55, 50, 45, and $40{ }^{\circ} \mathrm{C}$, the increase in the heat transfer effectiveness for the counter flow over the parallel flow are $2.74 \%, 5.00 \%, 4.17 \%$, and $2.70 \%$, respectively.

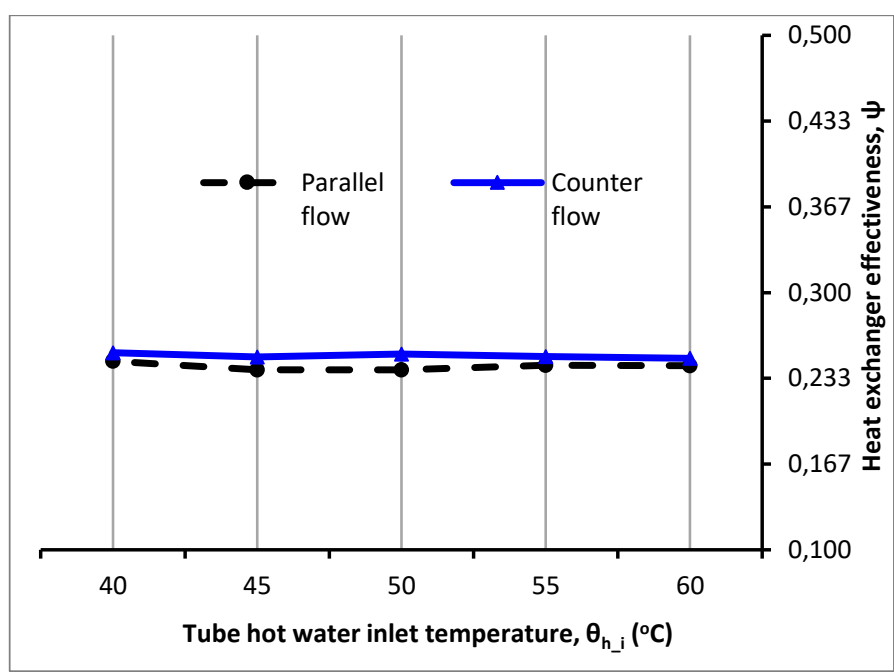

Fig. 3. Heat exchanger effectiveness for different flow configurations for the uninsulated shell 
TABLE I: EXPERIMENTAL DATA For PARALLEL FlOW CONFIGURATION For THE CASE OF THE UNINSULATED SHELL

\begin{tabular}{|c|c|c|c|c|c|c|c|c|}
\hline $\begin{array}{c}\text { Inlet temp. } \\
\text { of tube hot water } \\
\qquad\left(\theta_{h_{-} i}\right),{ }^{\circ} \mathrm{C}\end{array}$ & $\begin{array}{c}\text { Outlet } \\
\text { temp. of } \\
\text { tube hot } \\
\text { water }\left(\theta_{h_{\_}}\right) \text {, } \\
{ }^{\circ} \mathrm{C}\end{array}$ & $\begin{array}{l}\text { Inlet temp. } \\
\text { of Shell's } \\
\text { cold water } \\
\left(\theta_{c_{-} i}\right),{ }^{\circ} \mathrm{C}\end{array}$ & $\begin{array}{c}\text { Outlet } \\
\text { temp. of } \\
\text { Shell's cold } \\
\text { water }\left(\theta_{c_{\_} o}\right) \text {, } \\
{ }^{\circ} \mathrm{C}\end{array}$ & $\begin{array}{c}\text { Hot water } \\
\text { specific heat } \\
\text { capacity }\left(C_{P_{-} h}\right) \text {, } \\
\mathrm{kJ} \cdot \mathrm{kg}^{-1} \cdot \mathrm{K}^{-1}[22]\end{array}$ & $\begin{array}{c}\text { Cold water } \\
\text { specific heat } \\
\text { capacity }\left(C_{P_{-} c}\right) \text {, } \\
\mathrm{kJ} \cdot \mathrm{kg}^{-1} \cdot \mathrm{K}^{-1}[22]\end{array}$ & $\begin{array}{l}\text { Hot water } \\
\text { Heat } \\
\text { capacity rate } \\
\left(m_{h} \cdot C_{P}\right) \text {, } \\
\mathrm{kJ} \cdot \mathrm{K}^{-1} \cdot \mathrm{s}^{-1}\end{array}$ & $\begin{array}{c}\text { Cold water } \\
\text { Heat capacity } \\
\text { rate }\left(m_{c} \cdot C_{P_{-} c}\right) \text {, } \\
\mathrm{kJ} \cdot \mathrm{K}^{-1} \cdot \mathrm{s}^{-1}\end{array}$ & $\begin{array}{c}\text { Effectiveness } \\
\text { of heat } \\
\text { exchanger }(\psi)\end{array}$ \\
\hline 60.0 & 51.5 & 25.0 & 42.0 & 4.1850 & 4.1800 & 1.2555 & 1.2540 & 0.2431 \\
\hline 55.0 & 47.7 & 25.0 & 39.0 & 4.1830 & 4.1800 & 1.2549 & 1.2540 & 0.2435 \\
\hline 50.0 & 44.0 & 25.0 & 36.0 & 4.1810 & 4.1800 & 1.2543 & 1.2540 & 0.2401 \\
\hline 45.0 & 40.2 & 25.0 & 32.0 & 4.1795 & 4.1800 & 1.2539 & 1.2540 & 0.2400 \\
\hline 40.0 & 36.3 & 25.0 & 30.0 & 4.1785 & 4.1800 & 1.2536 & 1.2540 & 0.2466 \\
\hline
\end{tabular}

TABLE II: EXPERIMENTAL DATA FOR COUNTER FlOW CONFIGURATION FOR THE CASE OF THE UNINSULATED SHELL

\begin{tabular}{|c|c|c|c|c|c|c|c|c|}
\hline $\begin{array}{c}\text { Inlet temp. } \\
\text { of tube hot water } \\
\qquad\left(\theta_{h_{-} i}\right),{ }^{\circ} \mathrm{C}\end{array}$ & $\begin{array}{c}\text { Outlet } \\
\text { temp. of } \\
\text { tube hot } \\
\text { water }\left(\theta_{h_{-} o}\right), \\
{ }^{\circ} \mathrm{C}\end{array}$ & $\begin{array}{l}\text { Inlet temp. } \\
\text { of Shell's } \\
\text { cold water } \\
\left(\theta_{c_{-} i}\right),{ }^{\circ} \mathrm{C}\end{array}$ & $\begin{array}{c}\text { Outlet } \\
\text { temp. of } \\
\text { Shell's cold } \\
\text { water }\left(\theta_{c_{\_} o}\right) \text {, } \\
{ }^{\circ} \mathrm{C}\end{array}$ & 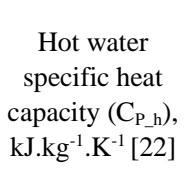 & $\begin{array}{c}\text { Cold water } \\
\text { specific heat } \\
\text { capacity }\left(C_{P_{-} c}\right) \text {, } \\
\mathrm{kJ} \cdot \mathrm{kg}^{-1} \cdot \mathrm{K}^{-1}[22]\end{array}$ & $\begin{array}{l}\text { Hot water Heat } \\
\text { capacity rate } \\
\left(m_{h \cdot} C_{P_{-} h}\right), \\
\mathrm{kJ} \cdot \mathrm{K}^{-1} \cdot \mathrm{s}^{-1}\end{array}$ & $\begin{array}{c}\text { Cold water } \\
\text { Heat capacity } \\
\text { rate }\left(m_{c} \cdot C_{P_{-} c}\right) \text {, } \\
\quad \mathrm{kJ} \cdot \mathrm{K}^{-1} \cdot \mathrm{s}^{-1}\end{array}$ & $\begin{array}{c}\text { Effectiveness } \\
\text { of heat } \\
\text { exchanger } \\
(\psi)\end{array}$ \\
\hline 60 & 51.3 & 25 & 42.0 & 4.1850 & 4.1800 & 1.2555 & 1.2540 & 0.2489 \\
\hline 55 & 47.5 & 25 & 39.0 & 4.1830 & 4.1800 & 1.2549 & 1.2540 & 0.2502 \\
\hline 50 & 43.7 & 25 & 36.0 & 4.1810 & 4.1800 & 1.2543 & 1.2540 & 0.2521 \\
\hline 45 & 40.0 & 25 & 32.0 & 4.1795 & 4.1800 & 1.2539 & 1.2540 & 0.2500 \\
\hline 40 & 36.2 & 25 & 30.0 & 4.1785 & 4.1800 & 1.2536 & 1.2540 & 0.2532 \\
\hline
\end{tabular}

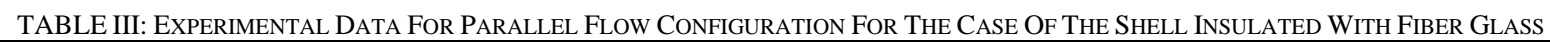

\begin{tabular}{|c|c|c|c|c|c|c|c|c|}
\hline $\begin{array}{c}\text { Inlet temp. } \\
\text { of tube hot water } \\
\qquad\left(\theta_{h_{-} i}\right),{ }^{\circ} \mathrm{C}\end{array}$ & $\begin{array}{l}\text { Outlet temp. } \\
\text { of tube hot } \\
\text { water }\left(\theta_{h_{-} o}\right) \text {, } \\
{ }^{\circ} \mathrm{C}\end{array}$ & $\begin{array}{l}\text { Inlet temp. } \\
\text { of Shell's } \\
\text { cold water } \\
\left(\theta_{c_{-} i}\right),{ }^{\circ} \mathrm{C}\end{array}$ & $\begin{array}{c}\text { Outlet } \\
\text { temp. of } \\
\text { Shell's cold } \\
\text { water }\left(\theta_{c_{-} o}\right) \text {, } \\
{ }^{\circ} \mathrm{C}\end{array}$ & $\begin{array}{c}\text { Hot water } \\
\text { specific heat } \\
\text { capacity }\left(C_{P_{-} h}\right) \text {, } \\
\mathrm{kJ} \cdot \mathrm{kg}^{-1} \cdot \mathrm{K}^{-1}[22]\end{array}$ & $\begin{array}{c}\text { Cold water } \\
\text { specific heat } \\
\text { capacity }\left(C_{P_{-} c}\right), \\
\mathrm{kJ} \mathrm{kg}^{-1} \cdot \mathrm{K}^{-1}[22]\end{array}$ & $\begin{array}{c}\text { Hot water } \\
\text { Heat capacity } \\
\text { rate }\left(m_{h} \cdot C_{P_{-} h}\right) \text {, } \\
\mathrm{kJ} \cdot \mathrm{K}^{-1} \cdot \mathrm{s}^{-1}\end{array}$ & $\begin{array}{c}\text { Cold water } \\
\text { Heat capacity } \\
\text { rate }\left(m_{c} \cdot C_{P_{-} c}\right) \text {, } \\
\quad \mathrm{kJ} \cdot \mathrm{K}^{-1} \cdot \mathrm{s}^{-1}\end{array}$ & $\begin{array}{c}\text { Effectiveness } \\
\text { of heat } \\
\text { exchanger } \\
(\psi)\end{array}$ \\
\hline 60 & 52.2 & 25 & 44.2 & 4.1850 & 4.1800 & 1.2555 & 1.2540 & 0.2231 \\
\hline 55 & 48.0 & 25 & 41.0 & 4.1830 & 4.1800 & 1.2549 & 1.2540 & 0.2268 \\
\hline 50 & 44.5 & 25 & 37.0 & 4.1810 & 4.1800 & 1.2543 & 1.2540 & 0.2201 \\
\hline 45 & 40.5 & 25 & 33.8 & 4.1795 & 4.1800 & 1.2539 & 1.2540 & 0.2250 \\
\hline 40 & 36.5 & 25 & 31.9 & 4.1785 & 4.1800 & 1.2536 & 1.2540 & 0.2266 \\
\hline
\end{tabular}

TABLE IV: EXPERIMENTAL DATA FOR COUNTER Flow CONFIGURATION For THE CASE Of THE SHELl INSULATED With FiBER GLASS

\begin{tabular}{|c|c|c|c|c|c|c|c|c|}
\hline $\begin{array}{l}\text { Inlet temp. } \\
\text { of tube hot water } \\
\qquad\left(\theta_{h_{-} i}\right),{ }^{\circ} \mathrm{C}\end{array}$ & $\begin{array}{l}\text { Outlet } \\
\text { temp. of } \\
\text { tube hot } \\
\text { water. } \\
\left(\theta_{h_{-} o}\right),{ }^{\circ} \mathrm{C}\end{array}$ & $\begin{array}{l}\text { Inlet temp. } \\
\text { of Shell's } \\
\text { cold water } \\
\left(\theta_{c_{-} i}\right),{ }^{\circ} \mathrm{C}\end{array}$ & $\begin{array}{l}\text { Outlet temp. } \\
\text { of Shell's } \\
\text { cold water } \\
\left(\theta_{c \_o}\right),{ }^{\circ} \mathrm{C}\end{array}$ & $\begin{array}{c}\text { Hot water } \\
\text { specific heat } \\
\text { capacity }\left(C_{P \_h}\right) \text {, } \\
\mathrm{kJ} \cdot \mathrm{kg}^{-1} \cdot \mathrm{K}^{-1}[22]\end{array}$ & $\begin{array}{c}\text { Cold water } \\
\text { specific heat } \\
\text { capacity }\left(C_{P_{-} c}\right) \text {, } \\
\mathrm{kJ} \cdot \mathrm{kg}^{-1} \cdot \mathrm{K}^{-1}[22]\end{array}$ & $\begin{array}{c}\text { Hot water Heat } \\
\text { capacity rate } \\
\left(m_{h} \cdot C_{P_{-} h}\right) \\
\mathrm{kJ} \cdot \mathrm{K}^{-1} \cdot \mathrm{s}^{-1}\end{array}$ & $\begin{array}{c}\text { Cold water } \\
\text { Heat capacity } \\
\text { rate }\left(m_{c} \cdot C_{P_{-}}\right) \text {, } \\
\mathrm{kJ} \cdot \mathrm{K}^{-1} \cdot \mathrm{s}^{-1}\end{array}$ & $\begin{array}{c}\text { Effectiveness } \\
\text { of heat } \\
\text { exchanger } \\
(\psi)\end{array}$ \\
\hline 60 & 52.1 & 25 & 46.4 & 4.1850 & 4.1800 & 1.2555 & 1.2540 & 0.2260 \\
\hline 55 & 47.9 & 25 & 43.0 & 4.1830 & 4.1800 & 1.2549 & 1.2540 & 0.2302 \\
\hline 50 & 44.4 & 25 & 38.0 & 4.1810 & 4.1800 & 1.2543 & 1.2540 & 0.2241 \\
\hline 45 & 40.5 & 25 & 35.6 & 4.1795 & 4.1800 & 1.2539 & 1.2540 & 0.2275 \\
\hline 40 & 36.5 & 25 & 33.8 & 4.1785 & 4.1800 & 1.2536 & 1.2540 & 0.2293 \\
\hline
\end{tabular}

The effects of insulating the outer surface of the shell with fiber glass for the two flow arrangements are graphically depicted in Fig. 4. As with the case of the uninsulated shell discussed above, the heat transfer effectiveness for the counter flow is greater compared to that of the parallel flow operating in similar conditions. Specifically, the effectiveness of heat transfer of the shelland-tube heat exchanger with fiber-glass-insulated shell for the parallel flow configuration when the tube hot water inlet temperature were $60,55,50,45$, and $40{ }^{\circ} \mathrm{C}$ are 0.2231 , $0.2268,0.2201,0.2250$, and 0.2266 , respectively. It is confirmed in Fig. 4 that the counter flow configuration operating under the same conditions has its corresponding heat transfer effectiveness increased by $1.28 \%, 1.47 \%$, $1.82 \%, 1.11 \%$, and $1.18 \%$, respectively, over that of the parallel flow arrangement.

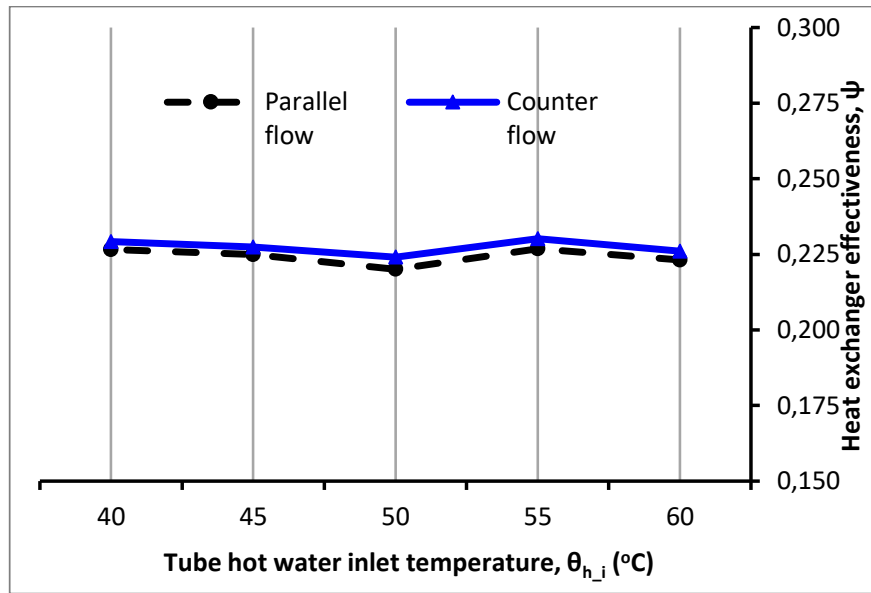

Fig. 4. Heat exchanger effectiveness for different flow configurations for the shell insulated with fiber glass. 
Moreover, the effectiveness of the heat exchanger, as it is affected by parallel flow arrangement and insulation of the shell is represented by Fig. 5. It is evident in the figure that when the tube hot water inlet temperature were $60,55,50$, 45 , and $40{ }^{\circ} \mathrm{C}$, the heat exchanger with an uninsulated shell has heat transfer effectiveness of $0.2431,0.2435,0.2401$, 0.2400 and 0.2466 . For the fiber- glass-insulated shell, the corresponding heat transfer effectiveness are 0.2231, $0.2268,0.2201,0.2250$, and 0.2266 , respectively. This means that for the parallel flow mode, the effectiveness of heat transfer of the heat exchanger whose shell was insulated decreases by approximately $8 \%$, compared with that of the heat exchanger with an uninsulated shell.

Fig. 6 illustrates the effects which the shell insulation for the case of counter flow mode has on the heat transfer effectiveness of the shell-and-tube heat exchanger. It can be observed that the heat transfer effectiveness of the heat exchanger with the shell insulated with fiber glass are $0.2260,0.2302,0.2241,0.2275$, and 0.2293 at the tube hot water inlet temperature of $60,55,50,45$, and $40{ }^{\circ} \mathrm{C}$, respectively. Furthermore, it can be deduced from the figure that the heat transfer effectiveness of the heat exchanger for the counter flow mode with an uninsulated shell increases by approximately $10 \%$ over that of the heat exchanger with an insulated shell. By interpretation, the effectiveness for the case of an uninsulated shell are 0.2489, 0.2502, 0.2521, 0.2500 , and 0.2532 at the tube hot water inlet temperature of $60,55,50,45$, and $40{ }^{\circ} \mathrm{C}$, respectively.

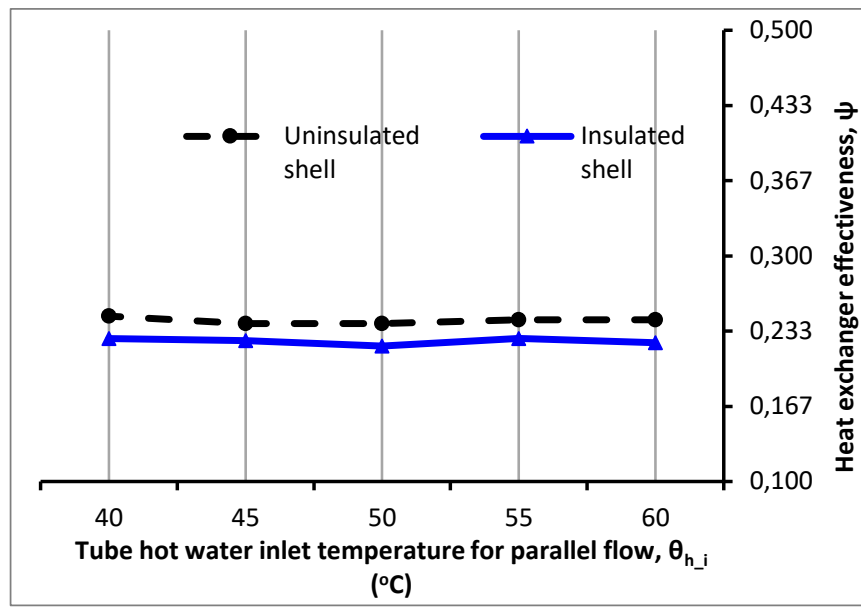

Fig. 5. Heat exchanger effectiveness for parallel flow configuration for the uninsulated shell and the fiber-glass-insulated shell.

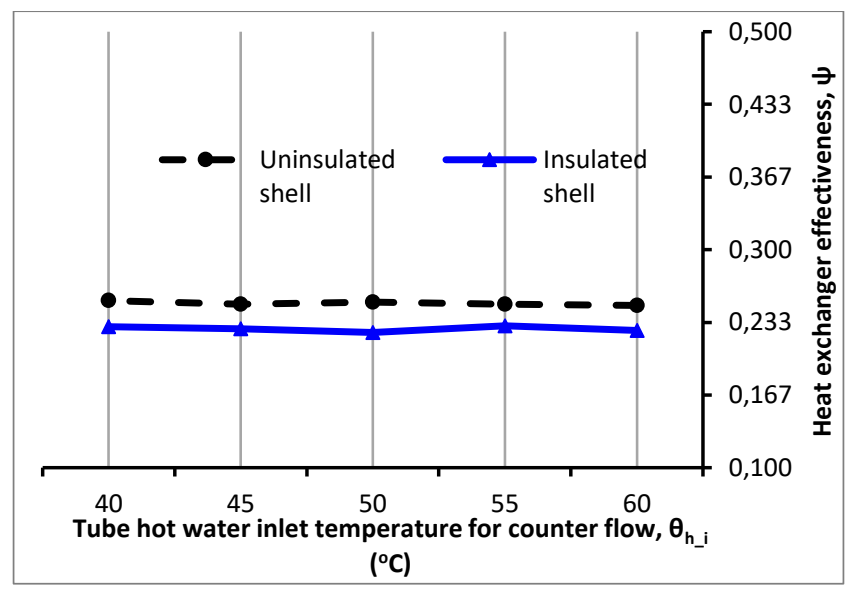

Fig. 6. Heat exchanger effectiveness for counter flow configuration for the uninsulated shell and the fiber-glass-insulated shell.

\section{CONCLUSIONS}

The following conclusions are obtained from this study:

A shell-and-tube heat exchanger was designed, fabricated, and subjected to multifaceted conditions, namely different temperatures of tube inlet hot water $(60,55,50,45$, and $40{ }^{\circ} \mathrm{C}$ ), parallel flow configuration, cross flow configuration, uninsulated shell, and fiber-glass-insulated shell. Investigations were conducted on the performance of the heat exchanger under the multifaceted conditions.

For the different tube inlet hot water temperatures to which the shell-and-tube heat exchanger with an uninsulated shell was subjected, the heat transfer effectiveness for the counter flow configuration is greater than that for the parallel flow configuration.

For the different tube inlet hot water temperatures to which the fiber-glass-insulated shell-and-tube heat exchanger was subjected, the heat transfer effectiveness for the counter flow configuration is greater than that for the parallel flow configuration.

The effectiveness of heat transfer of the shell-and-tube heat exchanger for the parallel flow and counter flow configurations for the uninsulated shell is greater than that for the fiber-glass-insulated shell operated under the same conditions of tube inlet hot water temperatures.

\section{DECLARATION OF CONFLICTING INTERESTS}

The authors declare that there are no conflicting interests with respect to the present work.

\section{NOMENCLATURE}

heat exchanger area $\left(\mathrm{m}^{2}\right)$ specific heat capacity of fluid (kJ/kg.K)

diameter $(\mathrm{m})$

heat exchanger length $(\mathrm{m})$

number

mass flow rate of fluid $(\mathrm{kg} / \mathrm{s})$

heat transfer (W)

temperature of fluid $\left({ }^{\circ} \mathrm{C}\right)$

heat transfer effectiveness

Subscripts

c cold fluid

h hot fluid

inlet, inside

maximum

minimum

outlet, outside

shell

tube

\section{REFERENCES}

[1] K. Thulukkanam, Heat Exchanger Design Handbook. 2nd ed., New York: CRC Press, 2013, pp. 1-3.

[2] Y. A. Kara and O. Guraras, "A computer program for designing of shell and tube heat exchanger," Appl. Therm. Eng., vol. 24, pp. 1797$1805,2004$.

[3] R. K. Shah and D. P. Sekulic, Fundamentals of Heat Exchanger Design. 1st ed., New Jersey: John Wiley \& Sons, Inc., 2003, pp. 1-8.

[4] A. O. Adelaja, S. J. Ojolo, and M. G. Sobamowo, "Computer aided analysis of thermal and mechanical design of shell and tube heat exchangers," Adv. Matl. Res., vol. 367, pp. 731-737, 2012.

[5] Y. A. Cengel, Heat Transfer - A Practical Approach. 2nd ed., New York: McGraw-Hill, 2002, ch. 13, pp. 669-671. 
[6] J. Yang, L. Ma, J. Liu, and W. Liu, "Thermal-hydraulic performance of a novel shell and- tube oil cooler with multi-fields synergy analysis," Int. J. Heat Mass Transf., vol. 77, pp. 928-939, 2014.

[7] R. Thundil-Karuppa-Raj and S. Ganne, "Shell side numerical analysis of a shell and tube heat exchanger considering the effects of baffle inclination angle on fluid flow using CFD," Therm. Sci., vol. 16, no. 4, pp. 1165-1174, 2012.

[8] M. O. Petinrin and A. A. Dare, "Performance of shell and tube heat exchangers with varying tube layouts," British J. Appl. Sci. Technol., vol. 12, no. 2, pp. 1-8, 2016.

[9] P. Shahmohammadi and H. Beiki, "A numerical investigation of $\gamma$ $\mathrm{Al}_{2} \mathrm{O}_{3}$-water nano fluids heat transfer and pressure drop in a shell and tube heat exchanger," Transp. Phenon. Nano Micro Scales, vol. 4, no. 1, pp. 29-35, 2016

[10] M. G. Yehia, A. A. A. Attia, O. E. Abdelatif, and E. E. Khalil, "Heat transfer and friction characteristics of shell and tube heat exchanger with multi inserted swirl vanes," Appl. Therm. Eng., vol. 102, pp. 1481-1491, 2016.

[11] H. S. Dizaji, S. Jafarmadar, and S. Asaadi, "Experimental exergy analysis for shell and tube heat exchanger made of corrugated shel and corrugated tube," Exp. Therm. Fluid Sci., vol. 81, pp. 475-481, 2017.

[12] A. Alimoradi and F. Veysi, "Optimal and critical values of geometrical parameters of shell and helically coiled tube heat exchangers," Case Studies Therm. Eng., vol. 10, pp. 73-78, 2017.

[13] A. A. Abd and S. Z. Naji, "Analysis study of shell and tube heat exchanger for clough company with reselect different parameters to improve the design," Case Studies Therm. Eng., vol. 10, pp. 455-467, 2017.

[14] C. Yu, Z. Ren, and M. Zeng, "Numerical investigation of shell-side performance for shell and tube heat exchangers with two differen clamping type anti-vibration baffles," Appl. Therm. Eng., vol. 133, pp $125-136,2018$

[15] B.-C. Du, Y.-L. He, Y. Qiu, Q. Liang, and Y.-P. Zhou, "Investigation on heat transfer characteristics of molten salt in a shell-and-tube hea exchanger," Int. Commun. Heat Mass Transf., vol. 96, pp. 61-68, 2018.

[16] Z. Khan and Z. A. Khan, "Thermodynamic performance of a novel shell-and-tube heat exchanger incorporating paraffin as therma storage solution for domestic and commercial applications," Appl. Therm. Eng., vol. 160, pp. 114007, 2019.

[17] G. Yang, G. Ding, J. Chen, W. Yang, and S. Hu, "Experimental study on shell side heat transfer characteristics of two-phase propane flow condensation for vertical helically baffled shell-and-tube exchanger," Int. J. Ref., vol. 107, pp. 135-144, 2019.

[18] E. M. S. El-Said and M. M. A. Al-Sood, "Shell and tube heat exchanger with new segmental baffles configurations: A comparative experimental investigation," Appl. Therm. Eng., vol. 150, pp. 803 $810,2019$.

[19] A. Khanlari, Y. D. Aydın, A. Sözen, M. Gürü, and H. İ. Variyenli, "Investigation of the influences of kaolin-deionized water nanofluid on the thermal behavior of concentric type heat exchanger," Heat Mass Transf., vol. 56, pp. 1453-1462, 2020.

[20] C. Yu, H. Zhang, M. Zeng, R. Wang, and B. Gao, "Numerical study on turbulent heat transfer performance of a new compound paralle flow shell and tube heat exchanger with longitudinal vortex generator," Appl. Therm. Eng., vol. 164, pp. 114449, 2020.

[21] T.-W. Lim and Y.-S. Choi, "Thermal design and performance evaluation of a shell-and-tube heat exchanger using LNG cold energy in LNG fuelled ship," Appl. Therm. Eng., vol. 171, pp. 115120, 2020.

[22] T. L. Bergman, A. S. Lavine, F. P. Incropera, and D. P. Dewitt, Fundamentals of Heat and Mass Transfer. 7th ed., USA: John Wiley \& Sons Inc., 2011, App. A.6, pp. 1003-1004

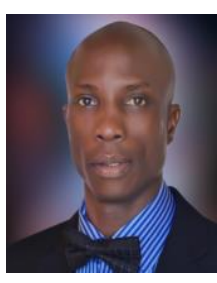

Taiwo O. Oni obtained a B.Eng degree, an M.Eng degree, and a $\mathrm{Ph} . \mathrm{D}$ degree in Mechanical Engineering from Ondo State University, AdoEkiti (now known as Ekiti State University, AdoEkiti), Nigeria, Federal University of Technology, Akure, Nigeria, and University of Glasgow, Glasgow, United Kingdom, respectively. His research areas are heat and mass transfer, fluid mechanics, thermodynamics, energy, refrigeration,

and air-conditioning

$\mathrm{He}$ is a Senior Lecturer in Department of Mechanical Engineering at Ekiti State University, Ado-Ekiti, Nigeria, and a member of Thermofluids Division within the Department. He is an author and a coauthor of several peer-reviewed articles published in reputable international journals and conference proceedings. He is also a coauthor of a textbook on fluid mechanics. Moreover, he is a reviewer of some reputable international journals.

Dr. Oni is a member of International Association of Engineers (IAENG) Hong Kong in China, Council for the Regulation of Engineering in Nigeria (COREN), and Nigerian Society of Engineers (NSE). His other professional memberships are Nigerian Institution of Mechanical Engineers (NIMechE), and Chartered Management Institute (CMI), UK.

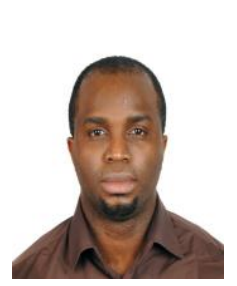

Ayotunde A. Ojo is a native of Usi-Ekiti, Nigeria. He obtained Bachelor of Engineering in Mechanical Engineering, University of Ado-Ekiti, Ado-Ekiti, Nigeria, (2005), Masters of Science in Advanced Engineering and Management, Sheffield Hallam University, Sheffield, United Kingdom, (2010), and $\mathrm{PhD}$ in Mechanical Engineering, Sheffield Hallam University, Sheffield, United Kingdom, (2017).

He is a lecturer in the Department of Mechanical Engineering, Faculty of Engineering, Ekiti State University, Ado-Ekiti. His areas of specialization are renewable energy (photovoltaics), material, and thermofluids.

Dr. Ojo is a corporate member of Nigeria Society of Engineers and a corporate member Nigerian Institution of Mechanical Engineers.

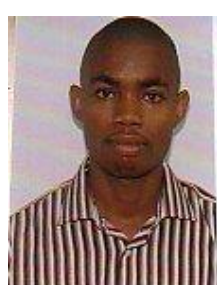

Daniel C. Uguru-Okorie received a B.Eng degree in Mechanical Engineering from the Federal University of Technology, Owerri, Nigeria in 2006 and MSc. and PhD degrees in Mechanical Engineering (Thermo-Fluids Option) from the University of Ibadan, Nigeria in 2010 and 2015 respectively. His research interests are in the areas of fuels and combustion in internal combustion engines, heat transfer and the development of renewable energy systems.

$\mathrm{He}$ is currently a lecturer in the Department of Mechanical and Mechatronics Engineering, Federal University, OyeEkiti, Ekiti State, Nigeria and was the immediate past Head of the Department of Mechanical Engineering, Landmark University, Omu Aran, Kwara state, Nigeria.

Dr. Uguru-Okorie is a COREN registered engineer, a corporate member of the Nigerian Society of Engineers (NSE) and a member of the Society of Automotive Engineers (SAE). He is a recipient of the Nigeria Sao Tome and Principe Joint Development Authority postgraduate scholarship, and the Petroleum Technology Development Fund (PTDF) PhD scholarship

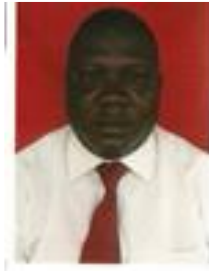

David O. Akindele holds a $\mathrm{PhD}$ degree in Mechanical Engineering obtained from University of Sheffield, United Kingdom in 2018. He is in the area of Thermofluids and energy resources with keen interest in Renewable Energy Resources. His teaching experience span through; teaching of Engineering Thermodynamics, Energy Technology, Internal Combustion Engines, Technical Drawing, and supervision of final year student's projects.

He is currently a Lecturer I officer in the Department of Mechanical Engineering at Ekiti State University, Ado-Ekiti. He has equally served the Department in various capacities such as a Level Adviser.

Dr. Akindelr has articles in some reputable journals and conference proceedings (local and international). He is married and the marriage is blessed with children. 